\title{
GESTATIONAL DIABETES MELLITUS AND ITS RELATIONSHIP WITH MACROSOMIA: A META ANALYSIS
}

\author{
Tantri Yunita Ratna'), Yulia Lanti Retno Dewi²), Bhisma Murti1) \\ ${ }^{1)}$ Masters Program in Public Health, Universitas Sebelas Maret \\ 2)Faculty of Medicine, Universitas Sebelas Maret
}

\begin{abstract}
Background: Fetal macrosomia was defined as a birth weight $\geq 4,000 \mathrm{~g}$. The increased risk of macrosomia in gestational diabetes mellitus is mainly due to the increased maternal insulin resistance. In gestational diabetes mellitus, a higher amount of blood glucose passes through the placenta into the fetal circulation. As a result, extra glucose in the fetus is stored as body fat causing macrosomia. The purpose of this study was to explore the impact of gestational diabetes mellitus on fetal macrosomia.

Subjects and Method: A systematic review and meta-analysis was carried out using PRISMA flow diagram. The articles were collected from PubMed, Science Direct, and Google Scholar databases, which published from 2000 to 2020. The keywords used including "gestational diabetes mellitus" OR "diabetes in pregnancy" AND macrosomia OR "perinatal outcomes". The inclusion criteria were full text, observasional study, using English language, and reporting adjusted Odds Ratio for multivariate analysis. Articles that met the criteria were analysis using Revman 5.3 software application.

Results: 12 cohort studies were reviewed for this study. This meta analysis reported that pregnant women with gestational diabetes mellitus increased the risk to deliver macrosomia babies 1.36 times than those without gestational diabetes mellitus (aOR= $1.36 ; 95 \% \mathrm{CI}=1.15$ to $1.60 ; \mathrm{p}=0.003$ ).

Conclusion: Diabetes mellitus increases the risk to macrosomia than those without gestational diabetes mellitus.
\end{abstract}

Keywords: gestational diabetes mellitus, macrosomia, meta analysis

\section{Correspondence:}

Tantri Yunita Ratna. Masters Program in Public Health, Universitas Sebelas Maret. Jl. Ir. Sutami 36A, Surakarta 57126, Central Java. Email: tantriyunita66@gmail.com. Mobile:082338868869 